\title{
Photoelectrochemical Behavior of n-type Si(100) Electrodes Coated with Thin Films of Manganese Oxide Grown by Atomic Layer Deposition
}

\author{
Nicholas C. Strandwitz, ${ }^{\ddagger}$ David J. Comstock, ${ }^{\dagger}$ Ronald L. Grimm, ${ }^{\ddagger}$ Adam C. Nichols-Nielander, ${ }^{\ddagger}$ \\ Jeffrey Elam, ${ }^{\dagger}$ and Nathan S. Lewis ${ }^{*},+$ \\ ${ }^{\dagger}$ Energy Systems Division, Argonne National Laboratory, Argonne, Illinois 60439, United States \\ ${ }^{\ddagger}$ Division of Chemistry and Chemical Engineering, Beckman Institute and Kavli Nanoscience Institute, 210 Noyes Laboratory, \\ California Institute of Technology, Pasadena, California 91125, United States
}

Supporting Information

ABSTRACT: Thin $(10 \mathrm{~nm})$ films of manganese oxide have been deposited by atomic layer deposition (ALD) onto n-type silicon and onto degenerately doped p-type silicon. The photoelectrochemical properties of the resulting semiconductor/metal-oxide structures were evaluated in contact with aqueous $0.35 \quad \mathrm{M} \mathrm{K}_{4} \mathrm{Fe}(\mathrm{CN})_{6}-0.05 \mathrm{M}$ $\mathrm{K}_{3} \mathrm{Fe}(\mathrm{CN})_{6}, 1.0 \mathrm{M} \mathrm{KOH}(\mathrm{aq})$, as well as in contact with a series of nonaqueous oneelectron, reversible, outer-sphere redox systems. Under simulated air mass (AM) 1.5 illumination in contact with $0.35 \mathrm{M} \mathrm{K}_{4} \mathrm{Fe}(\mathrm{CN})_{6}-0.05 \mathrm{M} \mathrm{K}_{3} \mathrm{Fe}(\mathrm{CN})_{6}(\mathrm{aq})$, MnO-coated $\mathrm{n}$-Si photoanodes displayed open-circuit voltages of up to $550 \mathrm{mV}$ and stable anodic

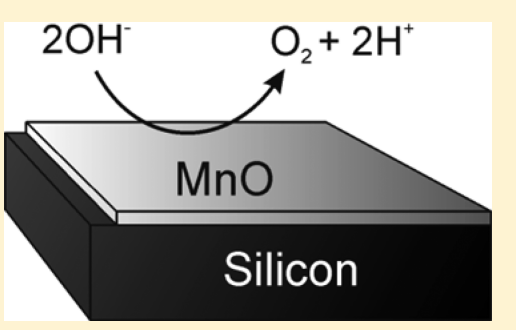
currents for periods of hours at $0.0 \mathrm{~V}$ versus the solution potential. In contact with $1.0 \mathrm{M}$ $\mathrm{KOH}(\mathrm{aq})$, at current densities of $\sim 25 \mathrm{~mA} \mathrm{~cm}{ }^{-2}, \mathrm{MnOlSi}$ photoanodes under $100 \mathrm{~mW} \mathrm{~cm} \mathrm{~m}^{-2}$ of simulated AM 1.5 illumination yielded stable oxygen evolution for 10-30 min. Variation in the thickness of the $\mathrm{MnO}$ films from 4 to $20 \mathrm{~nm}$ indicated the presence of a series resistance in the $\mathrm{MnO}$ film that limited the fill factor and thus the solar energy-conversion efficiency of the photoelectrodes. Open-circuit photovoltages of 30 and $450 \mathrm{mV}$, respectively, were observed in contact with cobaltocene ${ }^{+/ 0}$ or ferrocene ${ }^{+/ 0}$ in $\mathrm{CH}_{3} \mathrm{CN}$, indicating that the energetics of the MnO-coated Si surfaces were a function of the electrochemical potential of the contacting electrolyte solution.

\section{INTRODUCTION}

Stabilization of semiconductor surfaces is important for a variety of applications, including photoelectrochemical (PEC) devices. The group IV, III-V, and II-sulfide semiconductors can be produced with excellent electronic quality but are chemically unstable under photoanodic water oxidation conditions. ${ }^{1}$ Conversely, many metal oxides are stable under such oxidizing conditions but thus far lack the electronic properties required to produce efficient solar-driven watersplitting devices.

One approach to enhancing the stability of covalently bonded, small band gap $(<2 \mathrm{eV})$ photoanodes involves coating such materials with thin films that allow interfacial transfer of photogenerated minority carriers while chemically protecting the electrode surface from photocorrosion or photopassivation. Thin inorganic films that have been examined as protective coatings on semiconductor electrodes include $\mathrm{Fe}_{2} \mathrm{O}_{3}{ }^{2-6}$ $\mathrm{MgO},{ }^{7,8} \mathrm{TiO}_{2},{ }^{9-13} \mathrm{SrTiO}_{3}{ }^{12,14,15} \mathrm{Pd} \mathrm{MnO}, \mathrm{Pt} \mid \mathrm{MnO}_{2},{ }^{16,17}$ $\mathrm{SnO}_{2},{ }^{12,13,18,19} \mathrm{Ni} / \mathrm{NiO},{ }^{20,21} \mathrm{Sn}-\mathrm{In}_{2} \mathrm{O}_{3}{ }^{22-25} \mathrm{BP},{ }^{26}$ metal silicides, ${ }^{27}$ and a variety of metals. ${ }^{18,20,28-31}$ Specifically, iron oxide films have been deposited onto $\mathrm{n}-\mathrm{Si}$ by reactive evaporation ${ }^{4}$ and by CVD. ${ }^{32} \mathrm{Si}$ and GaAs photoanodes have been stabilized by manganese oxide films that were grown by chemical bath deposition on thin Pd and Pt layers. ${ }^{16,17}$ More recently, $\mathrm{n}$-Si has been stabilized for short periods of time at low current densities $\left(\sim 1 \mathrm{~mA} \mathrm{~cm}{ }^{-2}\right)$ by $\mathrm{NiO}$ films that were deposited using sol-gel techniques. ${ }^{21} \mathrm{Si}$ photoanodes have also shown enhanced stability for water oxidation in a wide $\mathrm{pH}$ range by use of atomic layer deposition to produce a thin film of $\mathrm{TiO}_{2}(2 \mathrm{~nm})$ followed by electron-beam evaporation of a thin film of $\operatorname{Ir}(3 \mathrm{~nm})$. $^{9}$

Producing high-quality thin films that reduce or halt photocorrosion without attenuating charge transport remains challenging. Dielectric layers that are sufficiently thin to allow for appreciable tunneling currents generally have a thickness of $\leq 2 \mathrm{~nm} \cdot{ }^{33,34}$ For such ultrathin films, nonuniformity over large areas, as well as cracks and pinholes, may present a challenge in achieving long-term stability of the photoelectrode. The deposition of noble metals in conjunction with growth of metal oxide protective overlayers does not rule out stabilization of the photoanode by the noble metal, rather than by the metal oxide film. ${ }^{9,16,17}$ In this work, we have investigated the utility of thicker $(>2 \mathrm{~nm})$ protective metal oxide films that are capable of transporting holes via state-mediated transport. The goal of the work was to assess whether deleterious corrosion and/or passivation processes can be suppressed while simultaneously

Received: November 12, 2012

Revised: January 18, 2013

Published: February 6, 2013 
maintaining high rates of interfacial charge transfer, and thus minimal resistance losses, in an operational semiconductorl liquid junction device. Accordingly, we describe the behavior of $\mathrm{n}$-type Si photoanodes coated with thin films of $\mathrm{MnO}$ that have been grown by atomic layer deposition (ALD).

\section{EXPERIMENTAL SECTION}

Chemicals/Materials. All experiments employed either ntype (phosphorus doped, $2 \Omega \mathrm{cm}$ resistivity, Silicon Quest International) or degenerately doped p-type (boron doped, resistivity $<0.005 \Omega \mathrm{cm}$, Silicon Quest International) (100)oriented, single-side polished Si wafers. The ALD precursor bis(diethylcyclopentadienyl) manganese, $\left(\mathrm{Et}_{2} \mathrm{Cp}\right)_{2} \mathrm{Mn}$, (Strem) was used without further purification, and $\mathrm{H}_{2} \mathrm{O}>18 \mathrm{M} \Omega \mathrm{cm}$ in resistivity was obtained from a Barnsted Nanopure system.

For the photoelectrochemical experiments, acetonitrile (99.8\% anhydrous, Sigma-Aldrich) was dried by use of a column of activated $\mathrm{Al}_{2} \mathrm{O}_{3}$, and lithium perchlorate (Sigma Aldrich, battery grade) was used as received. Ferrocene $\left(\mathrm{Cp}_{2} \mathrm{Fe}\right.$, bis(cyclopentadienyl)iron, 99\%, Strem), octamethyl ferrocene $\left(\mathrm{Me}_{8} \mathrm{Cp}_{2} \mathrm{Fe}\right.$, bis(tetramethylcyclopentadienyl)iron, Sigma Aldrich, 98\%), and cobaltocene ( $\mathrm{Cp}_{2} \mathrm{Co}$, bis(cyclopentadienyl)cobalt(II), 98\%, Strem) were individually purified by sublimation. Ferrocenium tetrafluoroborate $\left(\mathrm{Cp}_{2} \mathrm{Fe}^{+} \mathrm{BF}_{4}^{-}\right.$, bis(cyclopentadienyl)iron(III) tetrafluoroborate, technical grade, Sigma-Aldrich) was recrystallized from a diethyl ether (ACS grade, EMD)/acetonitrile (ACS grade, EMD) mixture and was dried under vacuum. Octamethylferrocenium $\left(\mathrm{Me}_{8} \mathrm{Cp}_{2} \mathrm{Fe}^{+} \mathrm{BF}_{4}^{-}\right.$, bis(tetramethylcyclopentadienyl)iron(III) tetrafluoroborate) was synthesized by chemical oxidation of octamethylferrocene $^{35}$ and was purified by recrystallization. Cobaltocenium hexafluorophosphate bis(cyclopentadienyl)cobalt(III) hexafluorophosphate, 98\%, Sigma-Aldrich), was recrystallized from an ethanol (ACS grade, EMD)/acetonitrile (ACS grade, EMD) mixture and was dried under vacuum. Potassium hydroxide (semiconductor grade, Sigma-Aldrich), $\mathrm{K}_{4} \mathrm{Fe}(\mathrm{CN})_{6}$, and $\mathrm{K}_{3} \mathrm{Fe}(\mathrm{CN})_{6}(99.0 \%$, Sigma-Aldrich) were used as received.

Atomic Layer Deposition. $\mathrm{MnO}$ films were deposited onto $\mathrm{Si}$ wafers by use of a Cambridge Nanotech S200 ALD system. The $\mathrm{Si}$ wafers were freshly etched with $\mathrm{HF}(\mathrm{aq})$ (Transene, Inc.) and were maintained at $150-200{ }^{\circ} \mathrm{C}$ during the ALD process. Following literature procedures, a single ALD cycle consisted of a $0.5 \mathrm{~s}$ pulse of $\left(\mathrm{Et}_{2} \mathrm{Cp}\right)_{2} \mathrm{Mn}$, a $20 \mathrm{~s}$ purge, a $0.015 \mathrm{~s}$ pulse of $\mathrm{H}_{2} \mathrm{O}$, and a $20 \mathrm{~s}$ purge under a continuous flow of research-grade $\mathrm{N}_{2}(\mathrm{~g})$ at a flow rate of $20 \mathrm{sccm} .^{36}$

Electrode Preparation. Ohmic contact to the electrodes was formed by scratching In-Ga eutectic into the unpolished side of a Si wafer. Ag paste (SPI Supplies) was then used to attach a tinned-Cu wire to the sample. Electrodes were then encapsulated in epoxy (Hysol 1C).

Instrumentation. X-ray photoelectron (XP) spectra were obtained using a Surface Science Instruments M-Probe system previously employed for characterizing oxidation and passivation of silicon surfaces. ${ }^{37} \mathrm{XP}$ spectra were collected for the Si $2 \mathrm{p}, \mathrm{C} 1 \mathrm{~s}, \mathrm{O} 1 \mathrm{~s}$, and $\mathrm{Mn} 2 \mathrm{p}$ regions with a pass energy of $50 \mathrm{eV}$ for the collected photoelectrons and a base pressure $<2 \times 10^{-9}$ Torr. XPS data were evaluated using a custom LabVIEW software package. Spectroscopic ellipsometry data for $\mathrm{MnO}$ were acquired using a J.A.Woolam alpha SE system, and the data were fit using a Cauchey model.

Electrochemical data were obtained using a Princeton Applied Research Model 2273 or a Gamry Reference 600 potentiostat. A Pt wire reference electrode $(0.5 \mathrm{~mm}$ diameter, 99.99\% trace metals basis, Sigma-Aldrich) and a Pt gauze counter electrode (100 mesh, $99.9 \%$ trace metals basis, SigmaAldrich) were used for nonaqueous photoelectrochemical measurements. For each nonaqueous redox couple, the Nernstian cell potentials were quantified by cyclic voltammetric scans versus a $\mathrm{Ag} / \mathrm{Ag}^{+}$reference electrode prior to and following the addition of a ferrocene standard. All acquired cell potentials were referenced to the potential of the saturated calomel electrode, SCE, by the conversion $E^{\mathrm{o} \prime}\left(\mathrm{Cp}_{2} \mathrm{Fe}^{+/ 0}\right)=$ $+0.311 \mathrm{~V}$ versus $\mathrm{SCE}$ for $\mathrm{Cp}_{2} \mathrm{Fe}^{+/ 0}$ in $1.0 \mathrm{M} \mathrm{LiClO}_{4}-\mathrm{CH}_{3} \mathrm{CN}$, with $E^{\mathrm{o} \prime}$ the formal potential of the redox system of interest. ${ }^{38}$ Data for oxygen evolution in $1 \mathrm{M} \mathrm{KOH}(\mathrm{aq})$ were collected in a three-compartment cell that was equipped with the $\mathrm{Si}$ photoelectrode, a $\mathrm{Ag} / \mathrm{AgCl}$ reference electrode, a $\mathrm{Pt}$ mesh counter electrode, and a NeoFox fluorescence in situ $\mathrm{O}_{2}$ detection system. No supporting electrolyte was used in conjunction with measurements involving the $\mathrm{K}_{4} \mathrm{Fe}(\mathrm{CN})_{6}-$ $\mathrm{K}_{3} \mathrm{Fe}(\mathrm{CN})_{6}$ (aq) redox couple.

For both aqueous-phase and nonaqueous photoelectrochemical experiments, illumination was provided by an ELH-type tungsten-halogen lamp. Light intensities were calibrated with a Si photodiode (Thor Laboratories) that was placed at the same location in the cell as the photoelectrodes with the Si diode calibrated relative to a secondary standard photodetector that was NIST-traceable and calibrated at $100 \mathrm{~mW} \mathrm{~cm}^{-2}$ of AM1.5 illumination. Measurment of photoelectrodes with metallocene redox couples was collected with and without $100 \mathrm{~mW} \mathrm{~cm}^{-2}$ of ELH-type tungsten-halogen illumination in a stirred glass electrochemical cell placed in an Ar-filled drybox that contained $<0.5$ ppm of $\mathrm{O}_{2}(\mathrm{~g})$.

\section{RESULTS}

Physical Characterization. X-ray photoelectron spectroscopy (XPS) on Si electrodes that had been functionalized with $2.5 \mathrm{~nm}$ thick $\mathrm{MnO}$ films (25 ALD cycles, $\sim 1 \AA$ per growth cycle) showed a peak in the $\mathrm{Si} 2 \mathrm{p}$ region at $102.2 \mathrm{eV}$ binding energy, indicating the presence of an interfacial $\mathrm{SiO}_{2}$ layer (Figure S1, Supporting Information). Spectroscopic ellipsometric data indicated that 100 ALD cycles produced $10 \mathrm{~nm}$ thick $\mathrm{MnO}$ films. The XP spectra (Figure S1, Supporting Information) from $10 \mathrm{~nm}$ thick $\mathrm{MnO}$ films yielded signals from $\mathrm{Mn}, \mathrm{O}$, and $\mathrm{C}$, but no $\mathrm{Si} 2 \mathrm{p}$ signal was observed from such samples.

Photoelectrochemistry with $1 \mathrm{M} \mathrm{KOH}$. Figure 1A presents the current density versus potential $(J-E)$ data for bare $\mathrm{n}$-Si, MnO-coated $(10 \mathrm{~nm}) \mathrm{n}-\mathrm{Si}(\mathrm{MnOln}-\mathrm{Si})$, and $\mathrm{MnO}$ coated $\mathrm{p}^{+}-\mathrm{Si}\left(\mathrm{MnOlp}^{+}-\mathrm{Si}\right)$ photoelectrodes in contact with 1.0 $\mathrm{M} \mathrm{KOH}(\mathrm{aq})$ under simulated 1 Sun illumination. As expected, bare $\mathrm{n}$-Si photoanodes passivated rapidly. ${ }^{39}$ In contrast, the $\mathrm{MnOln}-\mathrm{Si}$ electrodes were stable for $>20 \mathrm{~J}-E$ scans that passed illumination-limited current densities of $\sim 28 \mathrm{~mA} \mathrm{~cm}^{-2}$ at potentials $>500 \mathrm{mV}$ versus an $\mathrm{Ag} / \mathrm{AgCl}$ reference potential. The $\mathrm{MnOln}-\mathrm{Si}$ electrodes exhibited an onset potential of photoanodic current at a potential that was $\sim 50 \mathrm{mV}$ negative of the calculated formal potential for water oxidation $\left(E^{\mathrm{o} \prime}\left(\mathrm{O}_{2} /\right.\right.$ $\left.\mathrm{H}_{2} \mathrm{O}\right)=230 \mathrm{mV}$ versus $\mathrm{Ag} / \mathrm{AgCl}$ at $\mathrm{pH}$ 13.6). In the absence of illumination, $\mathrm{MnOlp}^{+}-\mathrm{Si}$ electrodes exhibited an anodic current onset at $\sim+600 \mathrm{mV}$ versus $\mathrm{Ag} / \mathrm{AgCl}$. Illuminated $\mathrm{MnOln}-\mathrm{Si}$ electrodes exhibited a current density of $10 \mathrm{~mA} \mathrm{~cm}{ }^{-2}$ at 290 $\mathrm{mV}$ versus $\mathrm{Ag} / \mathrm{AgCl}$, whereas $\mathrm{MnOlp}^{+}-\mathrm{Si}$ required $790 \mathrm{mV}$ versus $\mathrm{Ag} / \mathrm{AgCl}$ to yield $10 \mathrm{~mA} \mathrm{~cm}^{-2}$ of anodic current density. 

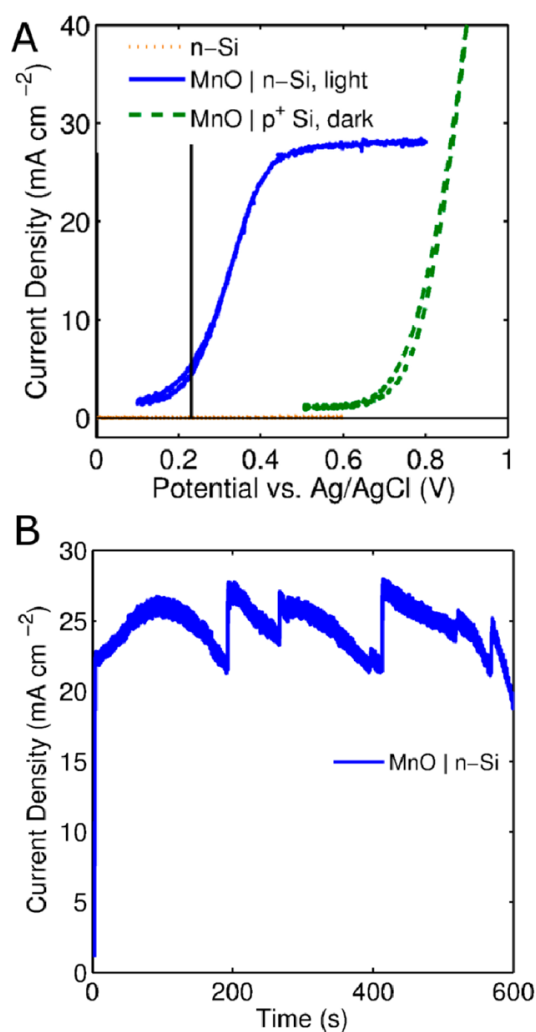

Figure 1. Photoelectrochemical behavior in $1.0 \mathrm{M} \mathrm{KOH}(\mathrm{aq})$ under $100 \mathrm{~mW} \mathrm{~cm}^{-2}$ of simulated solar illumination. (A) $J-E$ data for $\mathrm{n}-\mathrm{Si}$ photoelectrodes coated with $10 \mathrm{~nm} \mathrm{MnO}$. The vertical black line represents the calculated water oxidation potential $(+0.230 \mathrm{~V}$ versus $\mathrm{Ag} / \mathrm{AgCl})$ in $1 \mathrm{M} \mathrm{KOH}(\mathrm{aq})$ at atmospheric pressure. (B) Chronoamperometry of a $\mathrm{MnO}$-coated $\mathrm{n}$-Si sample under illumination at $0.600 \mathrm{~V}$ versus $\mathrm{Ag} / \mathrm{AgCl}$.

Hence, under these conditions the illuminated MnOln-Si electrodes produced a photovoltage of $\sim 500 \mathrm{mV}$.

Figure 1B displays chronoamperometric data for $\mathrm{MnO}$ coated $\mathrm{Si}$ photoelectrodes at $600 \mathrm{mV}$ versus $\mathrm{Ag} / \mathrm{AgCl}$ (Figure $1 B)$ in contact with $1 \mathrm{M} \mathrm{KOH}(\mathrm{aq})$ under simulated 1 Sun illumination. Uncoated $\mathrm{n}-\mathrm{Si}$ electrodes displayed negligible photocurrent, whereas $\mathrm{MnO} / \mathrm{n}$-Si electrodes displayed stable photoanodic current for $10-30 \mathrm{~min}$ at this potential. During passage of anodic current, bubbles were visible on the electrode and the spikes in current density values in Figure $1 \mathrm{~B}$ are attributable to bubble formation followed by rapid, periodic detachment from the photoelectrode surface. Additionally, the $\mathrm{O}_{2}$ concentration, measured by the fluorescent $\mathrm{O}_{2}$ probe, increased linearly with time. However, all of the electrodes eventually passivated and exhibited very small currents after sufficiently long time periods.

Photoelectrochemistry with $\mathrm{K}_{4} \mathrm{Fe}(\mathrm{CN})_{6}-\mathrm{K}_{3} \mathrm{Fe}(\mathrm{CN})_{6}$ (aq). Figure 2 displays the photoelectrochemical behavior of bare versus $\mathrm{MnO}$-coated $(10 \mathrm{~nm}) \mathrm{n}-\mathrm{Si}(100)$ photoanodes in contact with $0.35 \mathrm{M} \mathrm{K}_{4} \mathrm{Fe}(\mathrm{CN})_{6}-0.05 \mathrm{M} \mathrm{K} \mathrm{K}_{3} \mathrm{Fe}(\mathrm{CN})_{6}(\mathrm{aq})$. Under simulated $100 \mathrm{~mW} \mathrm{~cm} \mathrm{~cm}^{-2}$ of AM 1.5 illumination, MnOl $\mathrm{n}$-Si photoelectrodes exhibited open-circuit photovoltages of up to $550 \mathrm{mV}$ and light-limited current densities of $36 \mathrm{~mA} \mathrm{~cm}{ }^{-2}$. When poised at the Nernstian potential $\left(E\left(\mathrm{~A} / \mathrm{A}^{-}\right)\right)$of the solution, $\mathrm{MnOln}-\mathrm{Si}$ electrodes exhibited stable photocurrents for several hours, whereas bare $\mathrm{n}-\mathrm{Si}$ (100) surfaces quickly passivated and then exhibited low photovoltages and negligible photocurrents. $^{39}$
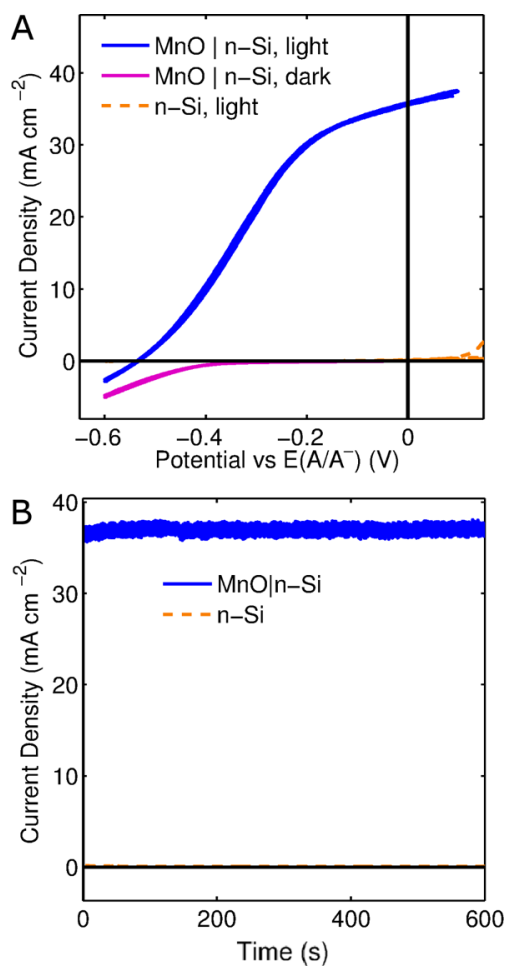

Figure 2. Photoelectrochemical behavior in $0.35 \mathrm{M} \mathrm{K}_{4} \mathrm{Fe}(\mathrm{CN})_{6}-0.05$ $\mathrm{M} \mathrm{K}_{3} \mathrm{Fe}(\mathrm{CN})_{6}(\mathrm{aq})$. (A) Current density versus potential $(J-E)$ data for $\mathrm{n}$-Si photoelectrodes with $10 \mathrm{~nm} \mathrm{MnO}$ films in the dark and under $100 \mathrm{~mW} \mathrm{~cm}{ }^{-2}$ simulated solar illumination. (B) Chronoamperometry of bare $\mathrm{n}$-Si and $\mathrm{MnO}$-coated $\mathrm{n}$-Si samples under illumination at $0 \mathrm{~V}$ versus solution potential.

Figure 3A shows the dependence of the short-circuit photocurrent density, $J_{s c}$ and $V_{o c}$ of $\mathrm{Si}$ photoanodes on the thickness of the ALD-grown $\mathrm{MnO}$ films. At small thicknesses (40 ALD cycles, $\sim 4 \mathrm{~nm}$ ), small and unstable photocurrents and photovoltages were observed. In contrast to the response of $n$ $\mathrm{Si}$ with thin $\mathrm{MnO}$ layers, thicker films (>80 ALD cycles) yielded stable $J_{\text {sc }}$ and $V_{\text {oc }}$ values with $V_{\text {oc }}$ decreasing slightly and $J_{\text {sc }}$ decreasing rapidly as the number of ALD cycles increased from 80 to 200. The resistance of the interfacial $\mathrm{SiO}_{2}$ and $\mathrm{MnO}$ films was calculated by subtracting the solution resistance and the resistance of the Si wafer from the observed total resistance that was derived from analysis of the $J-E$ data. The remaining resistance in the circuit, a series combination of the resistance due to the $\mathrm{SiO}_{2}$ and $\mathrm{MnO}$ layers, increased linearly with the $\mathrm{MnO}$ thickness. As demonstrated in Figure 3B, with thicknesses less than $5 \mathrm{~nm}$ higher resistances were observed than with $\mathrm{MnO}$ thicknesses greater than $5 \mathrm{~nm}$. Furthermore, for films $<5 \mathrm{~nm}$ in thickness, the resistance was not stable and increased with time, possibly indicating further oxidation of the underlying Si surface.

Photoelectrochemistry with Metallocene Redox Couples in $\mathrm{CH}_{3} \mathrm{CN}$. Figure 4 compares the open circuit photovoltage for illuminated $\mathrm{MnO}$-coated $\mathrm{n}$-Si photoelectrodes in contact with nonaqueous solutions of $\mathrm{Cp}_{2} \mathrm{Co}^{+/ 0}$, $\mathrm{Me}_{8} \mathrm{Cp}_{2} \mathrm{Fe}^{+/ 0}$, and $\mathrm{Cp}_{2} \mathrm{Fe}^{+/ 0}$ in $\mathrm{CH}_{3} \mathrm{CN}{ }^{40}$ In contact with

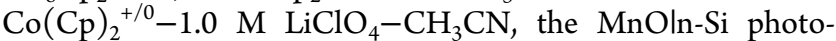
electrodes exhibited $V_{\mathrm{oc}}=30 \mathrm{mV}$ under ELH-type simulated 1 Sun illumination. In contact with $\mathrm{Me}_{8} \mathrm{Cp}_{2} \mathrm{Fe}^{+/ 0}-1.0 \mathrm{M}$ $\mathrm{LiClO}_{4}-\mathrm{CH}_{3} \mathrm{CN}, \quad V_{\mathrm{oc}}=400 \mathrm{mV}$, and in contact with $\mathrm{Cp}_{2} \mathrm{Fe}^{+/ 0}-1.0 \mathrm{M} \mathrm{LiClO}_{4}-\mathrm{CH}_{3} \mathrm{CN}, V_{\text {oc }}=450 \mathrm{mV}$. 

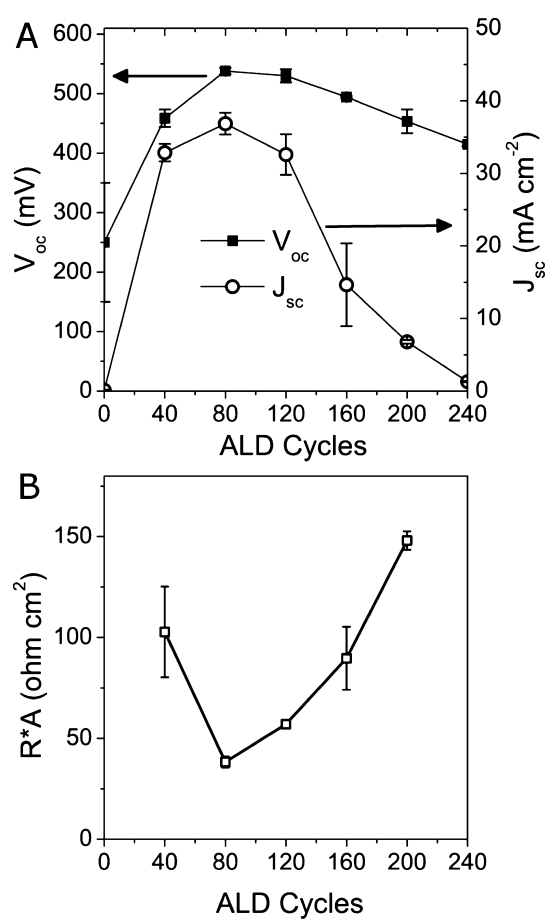

Figure 3. MnO-thickness dependent photoelectrochemical behavior measured under $100 \mathrm{~mW} \mathrm{~cm}{ }^{-2}$ simulated solar illumination in $0.35 \mathrm{M}$ $\mathrm{K}_{4} \mathrm{Fe}(\mathrm{CN})_{6}-0.05 \mathrm{M} \mathrm{K}_{3} \mathrm{Fe}(\mathrm{CN})_{6}(\mathrm{aq})$. (A) Open-circuit voltage $\left(V_{\mathrm{oc}}\right)$ and short-circuit $\left(J_{s c}\right)$ current density as a function of the thickness of the $\mathrm{MnO}$. (B) Area-specific resistance as function of the thickness of the $\mathrm{MnO}$.

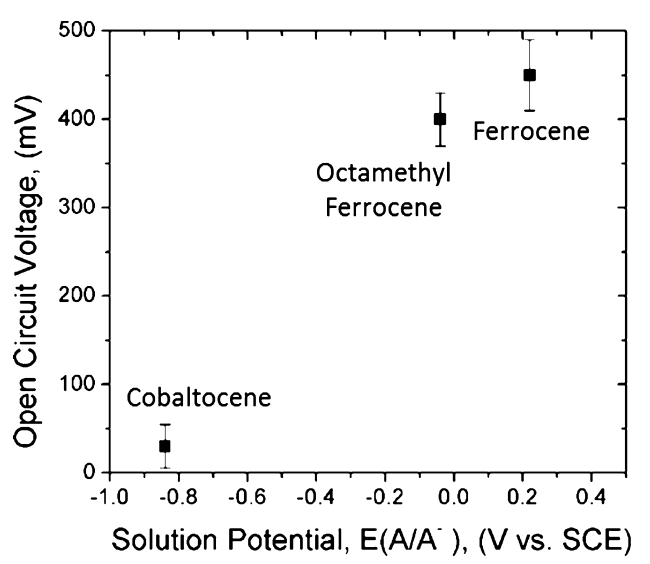

Figure 4. Open-circuit voltage $\left(V_{\text {oc }}\right)$ for MnOln-Si photoelectrodes under $100 \mathrm{~mW} \mathrm{~cm}{ }^{-2}$ white light illumination in various metallocene redox couples. Devices were measured in an Ar-filled glovebox with 1.0 $\mathrm{M} \mathrm{LiClO}_{4}$ in $\mathrm{CH}_{3} \mathrm{CN}$ along with the stated redox couple.

\section{DISCUSSION}

Photoelectrode Stability. The enhanced stability observed for $\mathrm{MnO}$-coated Si photoanodes relative to HF-etched $\mathrm{Si}(100)$ electrodes in contact with (aq)- $0.35 \mathrm{M} \mathrm{K}_{4} \mathrm{Fe}(\mathrm{CN})_{6}-$ $0.05 \mathrm{M} \mathrm{K}_{3} \mathrm{Fe}(\mathrm{CN})_{6}$ indicates that $\mathrm{ALD}$-grown films can provide a useful strategy for the reduction of passivation or corrosion processes on photoelectrode surfaces. The $\mathrm{MnO}$-coated $\mathrm{Si}$ surfaces are apparently more stable in contact with this aqueous reversible couple than has been reported for a $\mathrm{CH}_{3}$-terminated $\mathrm{Si}(111)$ surface, qualitatively attesting to the high degree of protection provided by the ALD layer. ${ }^{41}$ When MnOln-Si photoanodes were used to oxidize water, the ALD-grown $\mathrm{MnO}$ films also produced a significant decrease in, but not complete elimination of, the formation of a passivating oxide on the $\mathrm{Si}$ electrode surface.

The eventual passivation of the $\mathrm{MnO}$-coated $\mathrm{Si}$ photoelectrodes during oxygen evolution in $1 \mathrm{M} \mathrm{KOH}(\mathrm{aq})$ is consistent with expectations based on the electron conduction mechanism of $\mathrm{MnO}$ and redox cycling of $\mathrm{Mn}$ species at the $\mathrm{MnO}$ solution interface. $\mathrm{MnO}$ films exhibit large resistivity values, consistent with low carrier mobilities that are characteristic of highly localized charge carriers. ${ }^{42}$ Also, surface $\mathrm{Mn}$ species are expected to be driven to high oxidation states during oxygen evolution. ${ }^{4-45}$ Assuming an octahedral coordination environment, the structural changes that are associated with the redox cycling of $\mathrm{Mn}$ will result in changes in the ionic radius from approximately $82 \mathrm{pm}\left(2^{+}\right)$to $65 \mathrm{pm}\left(3^{+}\right)$to $54 \mathrm{pm}\left(4^{+}\right){ }^{46}$ These changes may induce porosity that will eventually lead to permeation of the electrolyte into the $\mathrm{MnO}$ film, followed by oxidation of the underlying Si. Consistently, anodization of metal films and metal oxide films has been shown to lead to structural changes, inducing porosity. ${ }^{47}$ An induced porosity that occurred over the entire exposed electrode surface is consistent with the observation that the failure of the $\mathrm{MnO}$ coated Si photoelectrodes during oxygen evolution occurred suddenly, rather than gradually. This behavior may also explain the electrode failure that has been previously observed when $n$ $\mathrm{Si}$ was coated with a thin film of $\mathrm{NiO} .^{21}$

Electrical Properties of $\mathrm{n}-\mathrm{Si} / \mathrm{MnO}$ Junctions. The variation in photovoltage that was observed for $\mathrm{MnOln}-\mathrm{Si}$ photoanodes as $E\left(\mathrm{~A} / \mathrm{A}^{-}\right)$was changed is consistent with a change in the effective barrier height in the semiconductor as a function of the electrochemical potential of the contacting phase. Hence, in contrast to metallsemiconductor contacts or semiconductor $\mathrm{p}-\mathrm{n}$ junctions ${ }^{48}$ for which the photovoltage is determined predominantly by the energetics of the metallurgical contact, the Fermi level of the MnOln-Si photoelectrodes is not pinned, and different barrier heights are obtained when the value of energetics of the contacting liquid phase are varied. This behavior could be explained by pinholes in the ALD film, which induce locally high or low barrier heights, or by the equilibration of the $\mathrm{MnO}$ layer with the solution phase, which will, in turn, influence the barrier in the n-Si.

The junction energetics are less well-defined for $\mathrm{MnOln}-\mathrm{Si}$ photoanodes in contact with $1.0 \mathrm{M} \mathrm{KOH}(\mathrm{aq})$, because the Nernst potential of such solutions is not defined by a kinetically rapid, reversible, one-electron charge-transfer process. Silicon and many other semiconductors are often dismissed as candidates for photoanodic water oxidation because of a lack of chemical stability and/or inappropriate band energetics. The data presented herein indicate that oxygen can be evolved in contact with $1 \mathrm{M} \mathrm{KOH}(\mathrm{aq})$ solutions at illuminated $\mathrm{MnO} / \mathrm{n}-\mathrm{Si}$ photoanodes with operation at potentials that are more negative than those required to produce $\mathrm{O}_{2}$ in the absence of illumination on $\mathrm{MnOlp}^{+}-\mathrm{Si}$ electrodes and that are more negative than $E^{\mathrm{O} \prime}\left(\mathrm{O}_{2} / \mathrm{H}_{2} \mathrm{O}\right)$. Indeed, two-electrode measurements with a dark, frit-isolated $\mathrm{Pt}$ counter electrode exhibited the same negative shift in $J-V$ data for MnOln-Si photoanodes relative to $\mathrm{MnOlp}^{+}-\mathrm{Si}$ electrodes as was observed in threeelectrode $J-E$ measurements (Supporting Information, Figure S2).

During oxygen evolution, the $J-E$ behavior of the $\mathrm{MnO} / \mathrm{Si}$ system was shifted by $-500 \mathrm{mV}$ (i.e., a bias reduction) $)^{49}$ between $\mathrm{MnOlp}^{+}-\mathrm{Si}$ and illuminated $\mathrm{MnOln}-\mathrm{Si}$ photoelectrodes 
(Figure 1). Consistent with other reports of modified Si photoelectrodes used for oxygen evolution, most of the photovoltage produced by the $\mathrm{Si}$ photoanode is used to overcome the sluggish kinetics for water or hydroxide oxidation. ${ }^{3,9,21}$ This observation is attributed to the accompanying large $(300-500 \mathrm{mV})$ overpotential requirements that are associated with driving the oxygen-evolution reaction at current densities of $\sim 10 \mathrm{~mA} \mathrm{~cm}{ }^{-2}$, coupled with the modest photovoltages produced by $\mathrm{Si}$ photoelectrodes $\left(V_{\mathrm{oc}}=500-\right.$ $600 \mathrm{mV}$ ). Thus, a photocathode that produced current densities of $\sim 10 \mathrm{~mA} \mathrm{~cm}{ }^{-2}$ at potentials of $\sim 1.2 \mathrm{~V}$ versus $E^{0 \prime}\left(\mathrm{H}^{+} / \mathrm{H}_{2}\right)$ would be required to achieve unassisted water splitting in a two-electrode cell that utilized a MnOln-Si photoanode. This behavior highlights the need for active catalysts for both the oxygen-evolution and hydrogen-evolution reactions, as well as the need to obtain an increase in opencircuit photovoltage, optimally approaching the estimated limit of $\left(V_{\mathrm{oc}}=\left(\boldsymbol{E}_{\mathrm{g}} / q\right)-400 \mathrm{mV}\right)$ for semiconductor absorbers.

Series Resistance in Si/MnO Photoelectrodes. The linear increase in resistance of the $\mathrm{MnO} / \mathrm{Si}$ electrodes with increases in the thickness of the $\mathrm{MnO}$ layer indicates that the dominant resistance is ascribable to the $\mathrm{MnO}$ film. The significant resistance of thin, ALD-grown, $\mathrm{MnO}$ is consistent with the low conductivity associated with $\mathrm{MnO}$ as well as with other Mott insulators. ${ }^{42}$

The trade-off between film conformality, corrosion/passivation protection, and electrical conductivity is clearly an important consideration for the beneficial use of ALD-grown films to protect photoelectrodes. $\mathrm{MnO}$ films that were sufficiently thin to produce acceptably low ohmic resistance drops $(<20-30 \mathrm{mV}$ of voltage drop at a current density of 20 $\mathrm{mA} \mathrm{cm}{ }^{-2}$ ) did not provide optimal enhancements of the stability of the $\mathrm{Si}$ photoanodes toward oxide growth, whereas thick films provided improved chemical protection but introduced large series resistances that degraded the solar energy-conversion properties of the resulting photoelectrodes. Films that fulfill these requirements simultaneously would be ideal for long-term, robust stabilization of photoanodes for water oxidation applications.

\section{CONCLUSIONS}

ALD-derived thin films can be used to enhance the stability of nonoxide semiconductor surfaces under otherwise chemically reactive conditions. Thin $\mathrm{MnO}$ films have been shown to stabilize $\mathrm{n}$-Si photoelectrodes in contact with aqueous electrolytes that contain a reversible redox couple, and photovoltages of up to $550 \mathrm{mV}$ were observed for protected $\mathrm{n}$-Si in contact with aqueous $0.35 \mathrm{M} \mathrm{K} \mathrm{K}_{4} \mathrm{Fe}(\mathrm{CN})_{6}-0.05 \mathrm{M} \mathrm{K} \mathrm{K}_{3} \mathrm{Fe}(\mathrm{CN})_{6}$. A similar photovoltage was inferred by the shift in the $J-E$ data between illuminated $\mathrm{MnO} / \mathrm{n}-\mathrm{Si}$ photoelectrodes and unilluminated $\mathrm{MnOlp}^{+}-\mathrm{Si}$ photoelectrodes in $1.0 \mathrm{M} \mathrm{KOH}$, where $\mathrm{O}_{2}$ evolution was observed. The photovoltage generated by $\mathrm{MnOl}$ $\mathrm{n}$-Si photoelectrodes was a function of the electrochemical potential of the contacting phase. Future challenges include simultaneously increasing the conductivity and stability of the protective layer.

\section{ASSOCIATED CONTENT}

\section{S Supporting Information}

$\mathrm{XP}$ spectra and additional current density versus potential data are available. This material is available free of charge via the Internet at http://pubs.acs.org.

\section{AUTHOR INFORMATION}

\section{Corresponding Author}

*Phone: 626-395-6335. E-mail: nslewis@caltech.edu.

\section{Notes}

The authors declare no competing financial interest.

\section{ACKNOWLEDGMENTS}

We acknowledge support from the NSF (CHE-1214152) and N.C.S. acknowledges the NSF for an American Competitiveness in Chemistry postdoctoral fellowship (CHE-1042006).

\section{REFERENCES}

(1) Gerischer, H. Photodecomposition of Semiconductors Thermodynamics, Kinetics and Application to Solar Cells. Faraday Discuss. Chem. Soc. 1980, 70, 137-151.

(2) Nogami, G.; Yamaguchi, H.; Maeda, G.; Beppu, K.; Ueda, Y.; Nakamura, T. XPS and AES Studies on Iron-Oxide-Coated Si Photoanodes with a Negative Flatband Potential. J. Appl. Phys. 1983, 54 (3), 1605-1609.

(3) Osaka, T.; Ejiri, K.; Hirota, N. Photoelectrochemical Behavior of Iron-Oxide N-Si Heterojunction Electrodes with an Outer Pd Layer. J. Electrochem. Soc. 1984, 131 (7), 1571-1574.

(4) Osaka, T.; Kitayama, H.; Hirota, N.; Eskildsen, S. S. Structural Analysis of Iron Oxide Coated n-silicon Heterojunction Photoanodes. Electrochim. Acta 1984, 29 (10), 1365-1370.

(5) Osaka, T.; Hirota, N.; Hayashi, T.; Eskildsen, S. S. Characteristics of Photoelectrochemical Cells with Iron-Oxide Normal-Si Heterojunction Photoanodes. Electrochim. Acta 1985, 30 (9), 1209-1212.

(6) Morisaki, H.; Ono, H.; Dohkoshi, H.; Yazawa, K. Iron-Oxide Coated $\mathrm{n}-\mathrm{Si}$ as a Heterostructure Photoanode for the Photoelectrolysis of Water. Jpn. J. Appl. Phys. 1980, 19, L148.

(7) Howe, A. T.; Hawkins, R. T.; Fleisch, T. H. Photoelectrochemical Cells of the Electrolyte-Metal-Insulator-Semiconductor (Emis) Configuration 0.3. Aspects Relating to Thermal Oxide-Growth in the Pt Silicon-Oxide N-Si System. J. Electrochem. Soc. 1987, 134 (4), 881886.

(8) Guo, L.; Hung, D.; Wang, W.; Shen, W.; Zhu, L.; Chien, C.-L.; Searson, P. C. Tunnel Barrier Photoelectrodes for Solar Water Splitting. Appl. Phys. Lett. 2010, 97 (6), 063111-3.

(9) Chen, Y. W.; Prange, J. D.; Dühnen, S.; Park, Y.; Gunji, M.; Chidsey, C. E. D.; McIntyre, P. C. Atomic Layer-deposited Tunnel Oxide Stabilizes Silicon Photoanodes for Water Oxidation. Nat. Mater. 2011, 10 (7), 539-544.

(10) Howe, A. T.; Fleisch, T. H. Photoelectrochemical Cells of the Electrolyte-Metal-Insulator-Semiconductor (Emis) Configuration 0.2. Use of Nonnative Oxides in Pt/Oxide/N-Si Systems. J. Electrochem. Soc. 1987, 134 (1), 72-76.

(11) Kohl, P. A.; Frank, S. N.; Bard, A. J. Semiconductor Electrodes. J. Electrochem. Soc. 1977, 124 (2), 225-229.

(12) Maruska, H. P.; Ghosh, A. K. Study of Oxide-Based Heterostructure Photoelectrodes. Sol. Energy Mater. 1979, 1 (5-6), 411-429.

(13) Tomkiewicz, M.; Woodall, J. M. Photoelectrolysis of Water with Semiconductor-Materials. J. Electrochem. Soc. 1977, 124 (9), 14361440.

(14) Campet, G.; Puprichitkun, C.; Sun, Z. W. Protection of Photoanodes Against Photocorrosion by Surface Deposition of Oxide Films: Criteria for Choosing the Protective Coating. J. Electroanal. Chem. Interfacial Electrochem. 1989, 269 (2), 435-445.

(15) Sun, Z. W.; Campet, G. Normal-GaAs Photoelectrodes Coated with $\mathrm{SrTiO}_{3}$-Based Films - Charge-Transfer Mechanisms and Stability. Mater. Sci. Eng., B 1990, 5 (4), 455-464.

(16) Kainthla, R. C.; Zelenay, B.; Bockris, J. O. Protection of N-Si Photoanode against Photocorrosion in Photoelectrochemical Cell for Water Electrolysis. J. Electrochem. Soc. 1986, 133 (2), 248-253. 
(17) Kainthla, R. C.; Zelenay, B.; Bockris, J. O. Significant Efficiency Increase in Self-Driven Photoelectrochemical Cell for Water Photoelectrolysis. J. Electrochem. Soc. 1987, 134 (4), 841-845.

(18) Belanger, D.; Dodelet, J. P.; Lombos, B. A. Characteristics and Stability of $\mathrm{N}-\mathrm{Si} / \mathrm{SnO}_{2}$ and $\mathrm{N}-\mathrm{Si} / \mathrm{SnO}_{2} / \mathrm{Pt}$ Photoanodes. J. Electrochem. Soc. 1986, 133 (6), 1113-1119.

(19) Decker, F.; Fracastorodecker, M.; Badawy, W.; Doblhofer, K.; Gerischer, H. The Photocurrent-Voltage Characteristics of the Heterojunction Combination $\mathrm{N}-\mathrm{Si} / \mathrm{SnO}_{2} /$ Redox-Electrolyte. J. Electrochem. Soc. 1983, 130 (11), 2173-2179.

(20) Li, G. Z.; Wang, S. X. Photoelectrochemical Characteristics of Metal-Modified Epitaxial N-Si Anodes 0.1. NiO(OH)-Coated N+/P-Si and $\mathrm{N}+/ \mathrm{N}-\mathrm{Si}$ Electrodes for Catalytic Oxygen Evolution. J. Electroanal. Chem. 1987, 227 (1-2), 213-221.

(21) Sun, K.; Park, N.; Sun, Z.; Zhou, J.; Wang, J.; Pang, X.; Shen, S.; Noh, S. Y.; Jing, Y.; Jin, S.; Yu, P. K. L.; Wang, D. Nickel Oxide Functionalized Silicon for Efficient Photo-oxidation of Water. Energy Environ. Sci. 2012, 5 (7), 7872-7877.

(22) Chyan, O. M. R.; Ho, S. I.; Rajeshwar, K. Heterojunction Photoelectrodes. J. Electrochem. Soc. 1986, 133 (3), 531-536.

(23) Hodes, G.; Thompson, L.; Dubow, J.; Rajeshwar, K. Heterojunction Silicon Indium Tin Oxide Photo-Electrodes Development of Stable Systems in Aqueous-Electrolytes and Their Applicability to Solar-Energy Conversion and Storage. J. Am. Chem. Soc. 1983, 105 (3), 324-330.

(24) Kraft, A.; Gorig, B.; Heckner, K. H. ITO Coated N-GaAs Electrodes for Photoelectrochemical Solar-Cells. Sol. Energy Mater. Sol. Cells 1994, 32 (2), 151-158.

(25) Kraft, A.; Rottmann, M.; Heckner, K. H. Photoelectrochemical properties of n-GaAs/ITO electrodes produced by dc sputtering. Sol. Energy Mater. Sol. Cells 1997, 45 (1), 97-103.

(26) Ginley, D. S.; Baughman, R. J.; Butler, M. A. BP-Stabilized Normal-Si and Normal-GaAs Photo-Anodes. J. Electrochem. Soc. 1983, 130 (10), 1999-2002.

(27) Fan, F. R. F.; Keil, R. G.; Bard, A. J. Semiconductor Electrodes. 48. Photooxidation of Halides and Water on N-silicon Protected with Silicide Layers. J. Am. Chem. Soc. 1983, 105 (2), 220-224.

(28) Contractor, A. Q.; Bockris, J. O. M. Investigation of a Protective Conducting Silica Film on N-Silicon. Electrochim. Acta 1984, 29 (10), 1427-1434.

(29) Howe, A. T.; Hawkins, R. T.; Fleisch, T. H. Photoelectrochemical Cells of the Electrolyte-Metal-Insulator-Semiconductor (Emis) Configuration 0.1. Metal Thickness and Coverage Effects in the Pt-Silicon Oxide-N-Si System. J. Electrochem. Soc. 1986, 133 (7), $1369-1375$

(30) Menezes, S.; Heller, A.; Miller, B. Metal Filmed Semiconductor Photoelectrochemical Cells. J. Electrochem. Soc. 1980, 127 (6), 12681273.

(31) Nakato, Y.; Iwakabe, Y.; Hiramoto, M.; Tsubomura, H. Tungsten-Coated or Molybdenum-Coated P-N-Junction Silicon Electrodes for Efficient and Stable Photoelectrochemical Solar-Energy Conversion. J. Electrochem. Soc. 1986, 133 (5), 900-904.

(32) Jun, K.; Lee, Y. S.; Buonassisi, T.; Jacobson, J. M. High Photocurrent in Silicon Photoanodes Catalyzed by Iron Oxide Thin Films for Water Oxidation. Angew. Chem., Int. Ed. 2012, 51 (2), 423427.

(33) Cowell, E. W.; Alimardani, N.; Knutson, C. C.; Conley, J. F.; Keszler, D. A.; Gibbons, B. J.; Wager, J. F. Advancing MIM Electronics: Amorphous Metal Electrodes. Adv. Mater. 2011, 23 (1), 74-78.

(34) Sze, S. M.; Ng, K. K. Physics of Semiconductor Devices, 3rd ed.; John Wiley \& Sons: Hoboken, NJ, 2007.

(35) Gray, H. B.; Hendrickson, D. N.; Sohn, Y. S. Magnetic susceptibility study of various ferricenium and iron(III) dicarbollide compounds. Inorg. Chem. 1971, 10 (8), 1559-1563.

(36) Burton, B. B.; Fabreguette, F. H.; George, S. M. Atomic layer deposition of $\mathrm{MnO}$ using Bis(ethylcyclopentadienyl)manganese and $\mathrm{H}_{2} \mathrm{O}$. Thin Solid Films 2009, 517 (19), 5658-5665.
(37) Bansal, A.; Li, X.; Yi, S. I.; Weinberg, W. H.; Lewis, N. S. Spectroscopic Studies of the Modification of Crystalline $\mathrm{Si}(111)$ Surfaces with Covalently-Attached Alkyl Chains Using a Chlorination/ Alkylation Method. J. Phys. Chem. B 2001, 105 (42), 10266-10277.

(38) Grimm, R. L.; Bierman, M. J.; O'Leary, L. E.; Strandwitz, N. C.; Brunschwig, B. S.; Lewis, N. S. Comparison of the Photoelectrochemical Behavior of H-Terminated and Methyl-Terminated $\mathrm{Si}(111)$ Surfaces in Contact with a Series of One-Electron, OuterSphere Redox Couples in CH3CN. J. Phys. Chem. C 2012, 116 (44), 23569-23576.

(39) Bolts, J. M.; Bocarsly, A. B.; Palazzotto, M. C.; Walton, E. G.; Lewis, N. S.; Wrighton, M. S. Chemically Derivatized N-type Silicon Photoelectrodes. Stabilization to Surface Corrosion in Aqueous Electrolyte Solutions and Mediation of Oxidation Reactions by Surface-attached Electroactive Ferrocene Reagents. J. Am. Chem. Soc. 1979, 101 (6), 1378-1385.

(40) Lewis, N. S. A Quantitative Investigation of the Open-Circuit Photovoltage at the Semiconductor/Liquid Interface. J. Electrochem. Soc. 1984, 131 (11), 2496-2503.

(41) Bansal, A.; Lewis, N. S. Stabilization of Si Photoanodes in Aqueous Electrolytes through Surface Alkylation. J. Phys. Chem. B 1998, 102 (21), 4058-4060.

(42) Cox, P. A. Transition Metal Oxides: An Introduction to Their Electronic Structure and Properties; Oxford University Press: New York, 2010; Vol. 27.

(43) Zaharieva, I.; Chernev, P.; Risch, M.; Klingan, K.; Kohlhoff, M.; Fischer, A.; Dau, H. Electrosynthesis, Functional, and Structural Characterization of a Water-oxidizing Manganese Oxide. Energy Environ. Sci. 2012, 5 (5), 7081-7089.

(44) Morita, M.; Iwakura, C.; Tamura, H. The Anodic Characteristics of Massive Manganese Oxide Electrode. Electrochim. Acta 1979, 24 (4), 357-362.

(45) Zaharieva, I.; Najafpour, M. M.; Wiechen, M.; Haumann, M.; Kurz, P.; Dau, H. Synthetic Manganese-calcium Oxides Mimic the Water-oxidizing Complex of Photosynthesis Functionally and Structurally. Energy Environ. Sci. 2011, 4 (7), 2400-2408.

(46) Shannon, R. D.; Prewitt, C. T. Effective Ionic Radii in Oxides and Fluorides. Acta Crystallogr., Sect. B 1969, 25 (5), 925-946.

(47) Jeong, D. J.; Kim, W.-S.; Choi, Y.-K.; Sung, Y.-E. Intercalation/ deintercalation Characteristics of Electrodeposited and Anodized Nickel Thin Film on ITO Electrode in Aqueous and Nonaqueous Electrolytes. J. Electroanal. Chem. 2001, 511 (1-2), 79-87.

(48) Boettcher, S. W.; Warren, E. L.; Putnam, M. C.; Santori, E. A.; Turner-Evans, D.; Kelzenberg, M. D.; Walter, M. G.; McKone, J. R.; Brunschwig, B. S.; Atwater, H. A.; Lewis, N. S. Photoelectrochemical Hydrogen Evolution Using Si Microwire Arrays. J. Am. Chem. Soc. 2011, 133 (5), 1216-1219.

(49) Heller, A. Hydrogen-Evolving Solar Cells. Science 1984, 223 (4641), 1141-1148. 